\title{
NEW RECORDS OF RHAPHIUM (DOLICHOPODIDAE, DIPTERA) FROM RUSSIAN PROTECTED AREAS
}

\author{
Olga O. Maslova ${ }^{1}$, Oleg P. Negrobov ${ }^{2, *}$, Olga V. Selivanova ${ }^{2}$ \\ ${ }^{1}$ Voronezh State Pedagogical University, Russia \\ ${ }^{2}$ Voronezh State University, Russia \\ *e-mail:negrobov@list.ru
}

Received: 09.02.2020. Revised: 04.04.2020. Accepted: 22.07.2020.

\begin{abstract}
The present study is based on examination of the collection funds of the Zoological Institute of RAS and the Department of Ecology and Systematics of Invertebrates of Voronezh State University. New data on the fauna of 29 Rhaphium species of Russia are provided. Rhaphium tuberculatum is recorded for the first time for the Russian fauna. Rhaphium patulum is recorded for the first time for Asia. The previously known data of distribution of Rhaphium species were supplemented and updated. In this paper, new records of faunal data were provided for 29 species of Rhaphium including the following species: Rhaphium albifrons, Rh. appendiculatum, Rh. brevicorne, Rh. commune, Rh. confine, Rh. crassipes, Rh. dichromum, Rh. discolor, Rh. elegantulum, Rh. fissum, Rh. johnrichardi, $R$ h. laticorne, Rh. latimanum, $R h$. lehri, Rh. micans, $R h$. monotrichum, Rh. nasutum, Rh. nigribarbatum, $R h$. obscuripes, $R h$. patellitarse, $R h$. patulum, $R h$. penicillatum, $R h$. rivale, $R h$. tibiale, $R h$. tridactylum, $R h$. tuberculatum. Rhaphium. johnrichardi, and Rh. tuberculatum are recorded for the first time after the descriptions. The previously known range of many species has been significantly expanded. New data for rare species, known from one or two regions of Russia, were obtained: Rhaphium boreale, Rh. confine, Rh. fissum, Rh. obscuripes, Rh. patulum, and $R h$. tibiale. As a result, currently 71 species of the genus Rhaphium are known from Russia.
\end{abstract}

Key words: flies, long-legged flies, national park, nature reserve, Palearctic, Rhaphiinae, species list

\section{Introduction}

The study of biodiversity is one of the most important fields of modern biology (Di Poi et al., 2011). Of particular importance is the study of the fauna of Protected Areas such as nature reserves for the conservation of species diversity (Fjeldså \& Loveti, 1977).

The genus Rhaphium (Meigen, 1803), included in the subfamily Rhaphiinae, comprises about 200 species in the world fauna (Grichanov, 2017). A review of the Palaearctic species of this genus carried out by Negrobov (1979), also provided the descriptions of all the Palearctic species and a key for their determination. A list of Dolichopodidae species of Russia was published with an analysis of all publications and indications for certain regions, including 66 species of the genus Rhaphium (Negrobov et al., 2013a). Two species and one subspecies were not included on that list of the genus in Russia. These were Rhaphium doroteum Negrobov 1979, described from the Irkutsk region and Primorsky Krai, Rh. terminale igorjani Negrobov, 1986 and Rh. neolatifacies Yang \& Wang, 2006, described from Sakhalin region (Negrobov, 1979, 1986; Yang et al., 2006).

Rhaphium hungaricum (Becker, 1918) and Rh. psilopodium (Becker, 1918) have been recorded for the first time for the Russian fauna from the Lipetsk region and Voronezh region (Negrobov, 2014). Rhaphium caucasicum Negrobov, Grichanov \& Selivanova, 2013 was described from the
North Caucasus (Negrobov et al., 2013b). In Chukotsky Autonomous Okrug, Grichanov (2018) recorded Rhaphium nigrum (Van Duzee, 1923), a species new for the Russian fauna.

Later, nine dolichopodid species were found from Russia including the following: $R h$. jamalense Negrobov, 1986 on the Yamal Peninsula, $R h$. macalpini Negrobov, 1986, Rh. johnrichardi Negrobov \& Grichanov, 2010 in the Primorsky Krai, Rh. brooksi Negrobov, Barkalov \& Selivanova, 2011 in the Kamchatsky Krai and the Magadan region, Rh. subtridactium Negrobov, Barkalov \& Selivanova, 2011 and $R h$. sibiricum Negrobov, Barkalov \& Selivanova, 2011 in the Republic of Altai, Rh. borisovi Negrobov, Barkalov \& Selivanova, 2012 on the Taimyr Peninsula and Rh. caucasicum Negrobov, Grichanov \& Selivanova, 2013 on the North Caucasus (Negrobov, 1986; Negrobov \& Onishchenko, 1991; Negrobov \& Grichanov, 2010; Negrobov et al., 2011, 2012, 2013a,b).

The aim of this paper was to study the distribution of Rhaphium species in Russia, including Protected Areas. The tasks of the study included the investigations of collection funds, and locations of rare species.

\section{Material and Methods}

The present study is based on an examination of the collection funds of the Zoological Institute 
of RAS and the Department of Ecology and Systematics of Invertebrates of the Voronezh State University. In addition, we studied the collections of the Insect Systematics Laboratory of the Zoological Institute of RAS, personal material of well-known specialists (e.g. N.A. Violovich, K.B. Gorodkov, L.S. Zimin, M.I. Rimsky-Korsakov, A.L. Chekanovsky) who were not an expert in dolichopodid systematics, but collected insects during research expeditions. Data collecting was made by O.P. Negrobov, his colleagues and students, as well as postgraduate students of the Voronezh State University (e.g. A.V. Barkalov, D.N. Golubtsov, V.V. Zlobin, I.S. Zhukov, V.D. Logvinovsky, S.I. Rybina, A.V. Tolstoy, Yu.A. Chernenko, I.V. Shamshev, M.N. Tsurikov). The material was collected on the following Protected Areas: Altai State Nature Reserve, Barguzinskiy State Nature Biosphere Reserve, Bashkir State Nature Reserve, Voronezh State Nature Biosphere Reserve, Caucasian State Nature Biosphere Reserve, Central Chernozem State Nature Reserve, Kandalaksha State Nature Reserve, Komandorskiy State Nature Reserve, Kronotsky State Nature Reserve, Stolby State Nature Reserve, Trans-Baikalsky National Park, Galichya Gora State Nature Reserve, Sikhote-Alin State Nature Biosphere Reserve, Smolenskoye Poozerye National Park, Taimyr State Nature Reserve, Teberda State Nature Reserve. A sweeping net was used for collecting flies.

\section{Results and Discussion}

About 3000 specimens were studied, and new data on the distribution of Rhaphium species in Russia were obtained. Below we present new records of the genus Rhaphium in regions of Russia.

\section{Rhaphium albifrons Zetterstedt, 1843}

Material examined: $1 \hat{\jmath}$, Sakhalin, Anivsky district, Urozhaynoye, 27.06.1973 (Logvinovsky); 1 ô, Sakhalin, Mount Chekhov, 03.08.1973 (Logvinovsky); 1 ô, Sakhalin, 32 $\mathrm{km}$ east from Alesandrosk-Sakhalinsky, village Tymovsky, 16.06.1982 (Shamshev); 3 Sakhalin, neighbourhoods of Yuzhno-Sakhalinsk, 06.07.1982 (Shamshev); 1 đ, Sakhalin, $45 \mathrm{~km}$ north from Yuzhno-Sakhalinsk, Bykov, 07.07.1982 (Shamshev); 1 Oे, Sakhalin, Novoaleksandrovsk, 07.08.1973 (Zlobin); $1 \hat{\jmath}$, Sakhalin, Moneron Island Natural Park, 26.08.1956 (Violovich).

Faunistic notes: In Russia, the species was known from the Leningrad region, Republic of Mor- dovia, Krasnoyarsky Krai, Republic of Altai, Irkutsk region, Khabarovsky Krai, and Primorsky Krai. It has been recorded for the first time on the Sakhalin Island and Moneron Island.

Rhaphium appendiculatum Zetterstedt, 1849 (Rh. macrocerum Meigen, 1824)

Material examined: 4 $\hat{\jmath}$, Krasnoyarsky Krai, Stolby State Nature Reserve, 11.07.2006 (Zhukov).

Faunistic notes: In European Russia, this species was distributed from the Leningrad region to the Crimea and the North Caucasus. It was also noted in the Republic of Altai. The new record has been found in Krasnoyarsky Krai.

\section{Rhaphium boreale Van Duzee, 1923}

Material examined: $4 \hat{\delta}$, Republic Buryatia, Barguzinskiy State Nature Biosphere Reserve, Davshe, 20.07.1965 (Negrobov); 1 Ô, Primorsky Krai, Sikhote-Alin State Nature Biosphere Reserve, $71 \mathrm{~km}$ west from Terney settlement, Serebryanka river bank, 14.08.1974 (Zlobin).

Faunistic notes: In Russia, this Holarctic northern species was known only from the Krasnoyarsky Krai and the Republic of Altai. It has been recorded for the first time in the Republic of Buryatia and the Primorsky Krai.

\section{Rhaphium brevicorne Curtis, 1835}

Material examined: $1 \hat{\delta}$, Republic of Adygea, Kurdzhipskaya, 23.06.1983 (Negrobov); 1 ठे, Republic of Adygea, Caucasian State Nature Biosphere Reserve, Lago-Naki, 04.07.1983 (Negrobov); 1 , Republic of Adygea, Caucasian State Nature Biosphere Reserve, Guzeripl, 20.06.1983 (Negrobov).

Faunistic notes: This species is known from Western Europe, while in Russia it was known only in Krasnodarsky Krai. We have recorded this species for the first time in the Republic of Adygea.

\section{Rhaphium caliginosum Meigen, 1824}

Material examined: $9 \hat{\jmath}$, Lipetsk region, Galichya Gora State Nature Reserve, Vorgolsky skaly, 15.07.1971 (Negrobov); 1 ô, Lipetsk region, Galichya Gora State Nature Reserve, Vorgolsky skaly, 14.07.1972 (Ivanov); 2 Oे, Southern Urals, Republic of Bashkiria, Bashkir State Nature Reserve, 18.07.1979 (Tolstoy); 4 ô, Altaisky Krai, Gorno-Altaysk, Altai State Nature Reserve, 15.07.1979 (Barkalov).

Faunistic notes: In European Russia this species was known from the Murmansk region to the North Caucasus, and in the south of Krasnoyarsky Krai. It has been recorded for the first time in the Republic of Altai and the Lipetsk region. 
Rhaphium commune (Meigen, 1824)

Material examined: $1 \hat{\partial}$, Lipetsk region, Galichya Gora State Nature Reserve, Vorgolsky skaly, 09.07.1971 (Negrobov).

Faunistic notes: In European Russia, this species was known from the Leningrad region to the Crimea and the North Caucasus and in the Republic of Yakutia. We have recorded this species for the first time in the Lipetsk region.

Rhaphium confine Zetterstedt, 1843

Material examined: $1 \curvearrowright$, Krasnodarsky Krai, Caucasian State Nature Biosphere Reserve, $23 \mathrm{~km}$ north from Krasnaya Polyana, Kishi river bank, 19.07.1981 (Shamshev); 6 §, Republic of Buryatia, Barguzinskiy State Nature Biosphere Reserve, 16.07.1965 (Negrobov).

Faunistic notes: In Russia, this species was known only from the Murmansk region and Taimyr Peninsula. It has been recorded for the first time in the North Caucasus (Krasnodarsky Krai), and the Republic Buryatia.

Rhaphium crassipes (Meigen, 1824)

Material examined: $1 \curvearrowright$, Taimyr Peninsula, 114 $\mathrm{km}$ from Khatanga along the river Kotui, 2-5.07.2010 (Barkalov); 1 đ̊, Taimyr Peninsula, Dudinka, Taimyr State Nature Reserve, 29.06.1976 (Chernenko).

Faunistic notes: In the Palearctic, the species is known from Western Europe to the Kamchatka Peninsula. It has been recorded for the first time in the Taimyr Peninsula.

Rhaphium dichromum Negrobov, 1976

Material examined: 3 , Lipetsk region, Galichya Gora State Nature Reserve, Vorgolsky scaly, 15.07.1971 (Negrobov).

Faunistic notes: In European Russia, the species was known from the Leningrad region, Voronezh region and from the North Caucasus and Crimea. In the Lipetsk region, the species has been recorded for the first time.

\section{Rhaphium discolor Zetterstedt, 1838}

Material examined: $1 \hat{\sigma}$, Arkhangelsk region, White Sea, Solovetsky Islands, Solovetsky State Historical, Architectural and Nature Museum-Reserve, 17.06.1895 (Rimsky-Korsakov); 5 ${ }^{\lambda}$, Republic of Buryatia, Barguzinskiy State Nature Biosphere Reserve, 11.07.1965 (Negrobov); 2 त, Republic of Buryatia, Ust-Barguzin, 08.08.1965 (Negrobov); 1 $\lambda$, mouth of the river Kiran, Chikoya Island (Republic of Buryatia), 29.07.1908 (Khomze).

Faunistic notes: In European Russia, this species was known from the Murmansk region, Lenin- grad region, Magadan region, Primorsky Krai. It has been recorded for the first time in the Arkhangelsk region and the Republic of Buryatia.

\section{Rhaphium elegantulum Meigen, 1824}

Material examined: $6 \hat{\sigma}$, Kursk region, Central Chernozem State Nature Reserve, Streletskaya steppe, 12.07.1971 (Rybina); 7 đ, Republic of Buryatia, Barguzinskiy State Nature Biosphere Reserve, 14.07.1965 (Negrobov); 4 今, Republic of Altai, lake Teletskoe, Artybash, Altai State Nature Reserve, 03.07.1972 (Logvinovskiy).

Faunistic notes: In Russia, the species was known from the Murmansk region to the North Caucasus, and in the Republic of Yakutia, Khanty-Mansi Autonomous Okrug, Krasnoyarsky Krai, and Novosibirsk region. It has been recorded for the first time in the Kursk region and the Republic of Altai.

\section{Rhaphium fissum Loew, 1850}

Material examined: $1 \curvearrowright$, Republic of Adygea, Caucasian State Nature Biosphere Reserve, cordon Tegenja, 24.06.1982 (Negrobov); 1 o, Republic of Adygea, Caucasian State Nature Biosphere Reserve, Tishkov cordon, 16.06.1963 (Negrobov).

Faunistic notes: In Russia, this species was found only in the Republic of Buryatia, Leningrad region, and Krasnoyarsky Krai (Negrobov \& Pogonin, 2006). It has been recorded for the first time in the North Caucasus (Republic of Adygea).

Rhaphium johnrichardi Negrobov \& Grichanov, 2010

Material examined: $1 \hat{\jmath}$, Irkutsk region, Listvyanka Trans-Baikalsky National Park, cape Cheremshan, 14.06.1941 (Chernovsky).

Faunistic notes: The species was described from the Primorsky Krai. It has been recorded for the first time in the Irkutsk region.

\section{Rhaphium laticorne Fallén, 1823}

Material examined: $5 \hat{\jmath}$, Lipetsk region, Galichya Gora State Nature Reserve, Vorgolsky skaly, 24.06.1971 (Negrobov).

Faunistic notes: In European Russia, the species was known from the Murmansk region to the North Caucasus and Crimea, in the Krasnoyarsky Krai and the Novosibirsk region. It has been recorded for first time in Lipetsk region.

\section{Rhaphium latimanum Kahanpää, 2007}

Material examined: $5 \hat{\jmath}$, Kamchatka, Esso, Bystraya river bank, Natural Park «Bystrinsky», 
29.06.1975 (Barkalov); 8 ふૈ, Kamchatka, Yelizovo, Avacha river bank, 13.06.1975 (Barkalov); 12 ô, Kamchatka, Kozyrevsk, Krekolka river bank, 20.06.1975 (Barkalov); 8 ふ, Kamchatka, 11 km from Petropavlovsk-Kamchatsky, 15.06.1975 (Barkalov).

Faunistic notes: In Russia, the species was known from the Khanty-Mansi Autonomous Okrug, Leningrad region, Moscow region, Magadan region, Khabarovsky Krai, Republic of Yakutia, Yamalo-Nenetsky Autonomous Okrug, and Taimyr. It has been recorded for the first time in Kamchatka.

\section{Rhaphium lehri Negrobov, 1977}

Material examined: $1 \stackrel{\jmath}{\partial}$, Orenburg region, SolIletsky district, Mayak, regional natural monument «Tract Stepnoy Mayak», 25.07.1933 (Zimin).

Faunistic notes: This species was recorded in North Kazakhstan. The record in the Voronezh region (Negrobov \& Shamshev, 1982) most likely refers to a new species.

Rhaphium micans Meigen, 1824

Material examined: $2 \widehat{\jmath}$, Kursk region, Central Chernozem State Nature Reserve, 09.07.1971 (Rybi-

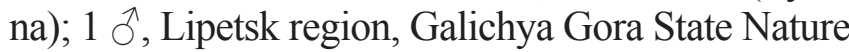
Reserve, Vorgolsky skaly, 10.07.1972 (Negrobov).

Faunistic notes: In European Russia, the species was known from the Leningrad region to the North Caucasus and the Astrakhan region, and in the Khabarovsky Krai and Krasnoyarsky Krai. It has been recorded for the first time in the Kursk region and the Lipetsk region.

\section{Rhaphium monotrichum Loew, 1850}

Material examined: 9 $\widehat{\jmath}$, Lipetsk region, Galichya Gora State Nature Reserve, Vorgolsky skaly, 15.07.1971 (Negrobov); 1 o, Republic of KarachayCherkessia, Teberda State Nature Reserve, 1300 m a.s.1., 02.06.1964 (Gorodkov); 1 ग, Irkutsk region, Listvyanka, Trans-Baikalsky National Park, 06.23.1965 (Negrobov).

Faunistic notes: In European Russia, the species was known from the Leningrad region to the North Caucasus and in the Lake Baikal. It has been recorded for the first time in the Lipetsk region and the Republic of Karachay-Cherkessia.

\section{Rhaphium nasutum (Fallen, 1823)}

Material examined: $1 \hat{\jmath}$, Murmansk region, Kandalaksha State Nature Reserve, Keretj, 23.07.1974 (Negrobov); 7 ते, Republic of Altai, Lake Teletskoe, Artybash, Altai State Nature Reserve, 07.07.1972 (Logvinovsky).
Faunistic notes: In Russia, this species was known in the middle and northern parts of the European part, in the Republic of Yakutia and the Krasnoyarsky Krai. It has been recorded for the first time in the Murmansk region and the Republic of Altai.

Rhaphium nigribarbatum Becker, 1900

Material examined: $1 \hat{\jmath}$, Primorsky Krai, Ussuriysk, Gorno- Tayozhnoe, Ussuriysk State Nature Reserve FEB RAS, 12.08.1980 (Sviridova).

Faunistic notes: This species is known in the middle and northern parts of European Russia, Republic of Yakutia, Republic of Altai and Krasnoyarsky Krai. It has been recorded for the first time in the Primorsky Krai.

\section{Rhaphium obscuripes Zetterstedt, 1849}

Material examined: $4 \hat{\delta}$, Voronezh region, Voronezh State Nature Biosphere Reserve, cordon Pridorozhnyi, 21.05.1979 (Negrobov).

Faunistic notes: In Russia, it was known only in the Republic of Karelia. It has been recorded for the first time in the Voronezh region.

\section{Rhaphium patellitarse Becker, 1900}

Material examined: $1 \hat{\jmath}$, Irkutsk region, Listvyanka, Trans-Baikalsky National Park, 28.06.1965 (Negrobov).

Faunistic notes: In Russia, the species was known from the Urals, Republic of Yakutia, Republic of Altai, Republic of Buryatia, the Yamalo-Nenetsky Autonomous Okrug, Taimyr. It has been recorded for the first time in the Irkutsk region.

\section{Rhaphium patulum Raddatz, 1873}

Material examined: $1 \hat{\sigma}$, Republic of Buryatia, Barguzinskiy State Nature Biosphere Reserve, Shumilikha river bank, 16.07.1975 (Negrobov).

Faunistic notes: In Russia, the species was known only from the Murmansk region and Leningrad region. It has been recorded for the first time in Asia.

\section{Rhaphium penicillatum Loew, 1850}

Material examined: $9 \hat{\sigma}$, Republic of Buryatia, Barguzinskiy State Nature Biosphere Reserve, Sosnovka, 24.07.1975 (Negrobov).

Faunistic notes: In Russia, the species was known from the Leningrad region, Voronezh region, Astrakhan region, the North Caucasus, and the Krasnoyarsky Krai. It has been recorded for the first time in the Republic of Buryatia. 
Rhaphium rivale Loew, 1869

Material examined: $1 \hat{\partial}$, Lipetsk region, Galichya Gora State Nature Reserve, Vorgolsky skaly, 05.07.1972 (Negrobov).

Faunistic notes: In Russia, this species was known from the Leningrad region, Republic of Yakutia, and the Krasnoyarsky Krai. It has been recorded for the first time in the European Russia.

\section{Rhaphium suavis Loew, 1859}

Material examined: $1 \hat{\partial}$, Lipetsk region, Galichya Gora State Nature Reserve, Vorgolsky skaly, 05.07.1972 (Negrobov).

Faunistic notes: In European Russia, this species was known from the Leningrad region, Voronezh region, Ryazan region, and the North Caucasus. It has been recorded for the first time from the Lipetsk region.

Rhaphium tibiale (von Roser, 1840)

Material examined: $1 \hat{\sigma}$, Voronezh region, Voronezh State Nature Reserve, 20.09.1963 (Negrobov); 1 ठ઼, Bering Island, Nikolskoe, Komandorskiy State Nature Reserve (Kamchatsky Krai), 22.08.1976 (Barkalov).

Faunistic notes: In Russia, it was known only from the Leningrad region. It has been recorded for the first time in the Voronezh region and on Bering Island.

\section{Rhaphium tridactylum Frey, 1915}

Material examined: $1 \hat{\partial}$, Kamchatka, Kronotsky State Nature Reserve, river Olga, 13.07.1988 (Golubtsov).

Faunistic notes: In Russia, the species was known from the Khabarovsky Krai, Taimyr and Sakhalin. It has been recorded for the first time in Kamchatka.

\section{Rhaphium tuberculatum Negrobov, 1983}

Material examined: $1 \hat{\sigma}$, Republic of Buryatia, Barguzinskiy State Nature Biosphere Reserve, 05.07.1965 (Negrobov).

Faunistic notes: The species was described from Mongolia on the basis of a single specimen. In Russia, it has been recorded for the first time.

\section{Conclusions}

New data were obtained on the fauna of 29 Rhaphium species for a number of Russian regions. Rhaphium tuberculatum has been recorded in Russia for the first time. Rhaphium patulum has been recorded for the first time in Asia. Three species (Rhaphium johnrichardi, Rh. lehri, and Rh. tuberculatum) have been found for the first time after their descriptions. New data were obtained on the following rare species, previously known only from one or two regions of Russia: Rhaphium boreale, $R h$. confine, Rh. fissum, Rh. obscuripes, Rh. patulum, and $R h$. tibiale. As a result, 71 Rhaphium species are currently known in Russia.

\section{Acknowledgments}

The reported study was funded by RFBR and NSFC according to the research project № 20-54-53005.

\section{References}

Di Poi C., Diss G.,Freschi L. 2011. Biodiversity matters in a changing world. Biology Letters 7(1): 4-6. DOI: 10.1098/rsbl.2010.0567

Fjeldså J., Loveti J.C. 1977. Biodiversity and environmental stability. Biodiversity and Conservation 6(3): 315-323. DOI: $10.1023 / \mathrm{A}: 1018304522320$

Grichanov I.Y. 2017. Alphabetic list of generic and specific names of predatory flies of the epifamily Dolichopodidae (Diptera). $2^{\text {nd }}$ ed. Plant Protection News Supplements 23: 442-455.

Grichanov I.Ya. 2018. An annotated checklist of Dolichopodidae (Diptera) of Chukotka (Russia) with new records. Acta Biologica Sibirica 4(2): 25-31. DOI: 10.14258/abs.v4i2.4120

Negrobov O.P. 1979. Dolichopodidae. In: E. Lindner (Ed.): Die Fliegen der Palaearktischen Region. Vol. 29. Lf. 322. Stuttgart: Schweizerbart'sche Verlagsbuchhandlung. P. 475-530.

Negrobov O.P. 1986. Holarctic communications of the fauna of the dolichopodid family. In: Biogeography of the Beringian sector of the Subarctic. Vladivostok. P. 161168. [In Russian]

Negrobov O.P. 2014. First Record of Two Species of the Genus Rhaphium (Dolichopodidae, Diptera) in Fauna of Russia. Vestnik Zoologii 48(1): 94.

Negrobov O.P., Grichanov I.Ya. 2010. The Rhaphium crassipes species group in the Palearctic Region with the description of a new species from Uzbekistan (Diptera: Dolichopodidae). Caucasian Entomological Bulletin 6(1): 117-122. DOI: 10.23885/1814-3326-2010-6-1-117-122

Negrobov O.P., Onishchenko V.V. 1991. New species of the family Dolichopolidae (Diptera) from Georgia. Zoologicheskii Zhurnal 70(11): 148-149. [In Russian]

Negrobov O.P., Pogonin S.V. 2006. Fauna of the species of the genus Rhaphium Meigen, 1803 (Diptera: Dolichopodidae) Krasnoyarsk region. Caucasian Entomological Bulletin 2(2): 219-220. [In Russian]

Negrobov O.P., Shamshev I.V. 1982. New data on the family Dolichopodidae (Diptera) in the south of the European part of the USSR. In: Issues of fauna and ecology of insects. Voronezh: Voronezh State University. P. 19-24. [In Russian]

Negrobov O.P., Barkalov A.V., Selivanova O.V. 2011. New dolichopodid species of the genera Dolichopus Latreille, 1797 and Rhaphium Meigen, 1803 (Diptera, Dolichopodidae) from Siberia. Euroasian Entomological Journal 10(2): 203-206. 
Negrobov O.P., Barkalov A.V., Selivanova O.V. 2012. Rhaphium Meigen (Diptera, Dolichopodidae) from the Taimyr Peninsula (Russia), with description of a new species. Zootaxa 3548(1): 75-87. DOI: 10.11646/zootaxa.3548.1.6

Negrobov O.P., Selivanova O.V., Maslova O.O., Chursina M.A. 2013a. Check-list of predatory flies of the family Dolichopodidae (Diptera) in the fauna of Russia. In: I.Ya. Grichanov, O.P. Negrobov (Eds.): Fauna and taxonomy of Doli- chopodidae (Diptera). Plant Protection News Suppl. St. Petersburg: VIZR RAAS. P. 47-93.

Negrobov O.P., Grichanov I.Ya., Selivanova O.V. 2013b. Palearctic species of the Rhaphium albifrons group (Diptera, Dolichopodidae). Euroasian Entomological Journal 12(6): 601-606.

Yang D., Zhu Y.J., Wang M.Q., Zhang L.L. 2006. World catalog of Dolichopodidae (Insecta: Diptera). Beijing: China Agricultural University Press: 704 p.

\title{
НОВЫЕ ДАННЫЕ ПО ФАУНЕ РОДА RHAPHIUM (DOLICHOPODIDAE, DIPTERA) ИЗ ООПТ РОССИИ
}

\author{
О. О. Маслова ${ }^{1}$, О. П. Негробов ${ }^{2, *}$, О. В. Селиванова ${ }^{2}$ \\ ${ }^{1}$ Воронежский государственный педагогический университет, Россия \\ ${ }^{2}$ Воронежский государственный университет, Россия \\ *e-mail:negrobov@list.ru
}

\begin{abstract}
Настоящее исследование связано с изучением коллекций Зоологического института РАН и кафедры экологии и систематики беспозвоночных животных Воронежского государственного университета. Получены новые данные о распространении в России 29 видов рода Rhaphium. Rhaphium tuberculatum впервые указан для территории России. Rhaphium patulum отмечается впервые для Азии. Ранее известное распространение многих видов значительно расширено. Впервые были получены новые данные о фауне для ряда территорий России для следующих видов: Rhaphium albifrons, $R h$. appendiculatum, $R h$. boreale, $R h$. brevicorne, $R h$. caliginosum, $R h$. commune, $R h$. confine, $R h$. crassipes, Rh. dichromum, Rh. discolor, Rh. elegantulum, Rh. fissum, Rh. johnrichardi, Rh. laticorne, Rh. latimanum, Rh. lehri, Rh. micans, Rh. monotrichum, Rh. nasutum, Rh. nigribarbatum, Rh. obscuripes, Rh. patellitarse, Rh. patulum, Rh. penicillatum, Rh. rivale, Rh. suavis, Rh. tibiale, Rh. tridactylum, Rh. tuberculatum. Виды Rhaphium johnrichardi и Rh. tuberculatum впервые указываться после первоописания. Получены новые данные для редких видов, которые были известны из одного или двух регионов России: Rhaphium boreale, Rh. confine, Rh. fissum, Rh. obscuripes, Rh. patulum и Rh. tibiale. К настоящему времени для фауны России известен 71 вид.
\end{abstract}

Ключевые слова: Rhaphiinae, двукрылые, зеленушки, национальный парк, Палеарктика, заповедник, список видов 